\title{
Are We "There" Yet?: A Comparative Analysis of the Canadian Standards on the Corporal Punishment of Children in Schools
}

\author{
By Caroline Locher-Lo*
}

\begin{abstract}
In 1973, British Columbia (B.C.) became the first province in Canada to forbid corporal punishment in public schools (B.C. School Act), followed by the majority of the other provinces. Alberta and Manitoba however, still have no provincially enacted legal prohibition, although many school boards have updated their policies to state that corporal punishment should be prohibited. The spotlight on efforts to repeal Section 43 of the Criminal Code may have dimmed over time on the national stage, but the recent Canadian Truth and Reconciliation report has ignited this issue once again. My article explores the existing laws with a comparative approach (Reimann \& Zimmermann, 2008; Orucu \& Nelken, 2007), in terms of where Canada stands in relation to other nations' legislative standards and practices. It also addresses the severe behavioural and psychological implications on impacted children. As a developed nation, Canada needs to reconsider its current state of "progress" by inspecting and reviewing existing discourses and legislatives to ensure successful prevention of corporal punishment in schools. This paper intends not only to contribute to the advancement of Canadian legislative standards, but also to practices in local and international education.
\end{abstract}

Keywords: abolition, corporal punishment, international standards, laws and legislatives, school children.

\section{Introduction}

The 6 volumes and over two million words of the Truth and Reconciliation report (TRC) drafted by the Commission of Canada was made publicly available in December 2015. It once again reignited a debate on the century-old question of whether the corporal punishment of children should be considered a private affair, or one regulated by the state. The Truth and Reconciliation Commission in its final report declared that corporal punishment is "a relic of a discredited past that has no place in Canadian schools or homes" (Truth and Reconciliation Commission of Canada, 2015, p. 144). Despite this statement sounding selfjustifiable, some Canadians prefer to reserve their support on such a view. Both sides of the argument have faithful supporters, and repealing or abolishing Section 43 of the Canadian Criminal Code has been fiercely discussed.

Canada is not alone in this matter. A 2010 publication by professors and researchers Taylor, Manganello, Lee and Rice, from Tulane University and various other Universities in the United States for the Journal of Paediatrics, has reinvigorated this moral dilemma in the mass media. The spotlight on

${ }^{*} \mathrm{PhD}$ Student/Research Assistant, University of British Columbia, Canada. 
corporal punishment may have dimmed for some time on the national and international stage, but the issue never really went away, as there have always been debates, initiatives and reviews at various levels in many parts of the world. The recent focus on addressing and reconciling issues for the healing process of First Nations residential school survivors is an exemplary and catalytic case revealing divergent perceptions and standards between and within the Canadian government, educators, parents and the general public on abolishing or repealing laws relating to corporal punishment.

Many may agree that in order to correct children's misbehaviour, at some point, parents, guardians or teachers may have to intervene or discipline them. But can we raise and educate children to behave better when we resort to spanking? From an anthropological or paediatric point of view, children are the most impressible group of humanity. Astonishing or horrifying experiences leave long term imprints on their memory (Riak, 2003). Even without an academic study's support, one can observe this from the engrained personal experiences of one's childhood.

Despite much discussion on the corporal punishment of children, are Canadians taking the matter seriously? Should corporal punishment be considered differently under different circumstances? Where does Canada stand today in this matter, compared to other developed nations? This paper employs a comparative approach to examine Canada's stance, at the international level, on the corporal punishment of children in schools. Given that Canada does not have one national education system, in the context of Canadian schools, I draw upon the United Nations' definition to operationalize corporal punishment as any form of bodily harm or physical punishment inflicted by adults, in this case educators.

\section{Where Does Canada Stand?}

As of today, laws enacted to prohibit corporal punishment in public schools are located as follows: British Columbia (1973), New Brunswick (1990), Nova Scotia (1989), the Yukon (1990), Prince Edward Island (1993), Nunavut (1995), the Northwest Territories (1995), Quebec (1997), Newfoundland (1997), Saskatchewan (2005), and Ontario (2009) (GIECP, 2015).

As one can see, British Columbia was the first province to ban corporal punishment in the public school setting, and more than sixteen years prior to the second province, Nova Scotia, in 1989. Alberta and Manitoba however still have no provincially enacted legislation, despite many school boards' current policies stating that corporal punishment should be forbidden (GIECPC, 2015, para 5). In addition, Ontario, despite having legislative prohibition since 2009, took no regulatory action on this matter. Rather, it encourages school boards to develop disciplinary approaches, which allows Ontario school boards to continue employing corporal punishment (ibid.).

Moreover, corporal punishment in the privacy of the home is still lawful everywhere in Canada. This includes foster care in most Canadian provinces, 
such as Saskatchewan, New Brunswick, Newfoundland, Nova Scotia, Prince Edward Island, Nunavut, the Northwest Territories, and the Yukon. On the other hand, all provinces and territories, except New Brunswick, have banned corporal punishment in child care (GIECPC, 2015, para 8).

\section{Where Are We Legislatively?}

The aforementioned Section 43 (S. 43) of the Canadian Criminal Code (1985) addresses the "Protection of Persons in Authority" and states:

"Every school teacher, parent or person standing in the place of a parent is justified in using force by way of correction toward a pupil or child, as the case may be, who is under his care, if the force does not exceed what is reasonable under the circumstances".

Quebec is the only province in Canada that properly recognizes the importance of protecting children from the hand of their "protectors". In 1994, Quebec changed its Civil Code by removing reference to a "right of correction", and several court rulings have demonstrated that Quebec's civil law no longer recognises this right (GIECPC, 2015). Nevertheless, teachers and parents can still rely on Section 43 of the Criminal Code to justify the corporal punishment of children; the federal law is paramount.

Several organizations and individuals have claimed that S. 43 violates the fundamental human rights of children under Sections 7 (Security), 12 (Punishment), and 15 (Equality) of The Canadian Charter of Rights and Freedoms (Brown \& Zuker, 2007). At a provincial level, as stated above, eight provinces and three territories in Canada have legally prohibited corporal punishment in public schools, but no provincial law has been enacted in this regard in Alberta or Manitoba.

\section{Where Are We Legally?}

On January 30th, 2004, the Supreme Court Chief Justice handed down the majority decision that Section 43 justifies only "minor corrective force of a transitory and trifling nature" (Durrant, Trocmé, Fallon, Milne, Black, \& Petrowski, 2009, p.4). It further stated that it rules out "Corporal Punishment of children under the age of two years or over the age of 12 years, as well as degrading, inhuman or harmful conduct; discipline using objects such as rulers or belts and blows or slaps to the head" (ibid). The ruling excluded corporal punishment by teachers from the applications of S. 43 and limited the use of force at schools to "restraint and removal", but this has not been confirmed in provincial education legislation for any Albertan or Manitoban schools or in relation to private schools (GIECPC, 2015, para 3).

In addition, the above judgement states that teachers are not allowed to use 
corporal punishment, however they may still apply "reasonable" force when they see fit, to remove a student from a classroom and to carry out their responsibilities (Watkinson, 2006).

In accordance with the 2004 ruling, the use of "minor corrective force" is still allowed in ten provinces and three territories but may only consist "of a transient and trifling nature." It also limits these actions with a minimum and maximum age, and the exclusive use of an open hand instead of other implements. Despite the more concrete limitations, the still-subjective guidelines open up wide possibilities for interpretations of the scope of "reasonable" and the definition of "corrective".

Furthermore, the reasons given for this ruling by six out of nine judges soon became controversial in the public eye. They had concluded that these provisions do not violate the Canadian Charter (Canadian Charter of Rights and Freedoms, 1982. s.7, $12 \& 15$ ) as they do not infringe on a child's right to "security of the person" (Watkinson, 2007, p.185-189) or "equal protection" (ibid), and do not constitute "cruel and unusual treatment or punishment" (ibid).

Under Canada's criminal law, the physical assault of any person, including children, is unlawful. Since the federal law is paramount over any provincial or territorial inconsistencies, the only way to standardize the law across the board would be to repeal Section 43. Barnett, an analyst for the Canadian government, expresses that the successful repeal of S. 43 would remove this legal inconsistency across Canada (Barnett, 2008).

Moreover, the Child Rights Information Network (CRIN) and many other organizations and individuals do not find the Supreme Court's 2004 judgement consistent with Canada's obligations under the United Nations (UN) Convention on the Rights of the Child, which Canada signed and ratified in 1991 (Canadian Children's Rights Council, n.d., para. 4) along with many other international communities, developed and less-developed.

\section{Are We on our Way?}

Starting in the late 1980s, there have been several legislative attempts to repeal Section 43 (Repeal 43 Committee, 2011, paras 1-5), most in the form of members' bills introduced in the Senate or House of Commons. In general chronological order, C-235, C-245, C-296, and C-305 were all introduced by Burnaby MP Svend Robinson, C-276, C-273 and C-329 by Vancouver MP Libby Davies, and C-368 by Toronto MP Tony Ianno. In the Senate, S-14, S21, S-207, S-209 and S-204 were introduced (Senate Bills to Repeal S.43, 2010, paras. 3-14; Senate Public Bill, 2011).

Due to various reasons, these bills did not proceed. For instance, in 2006 the ruling government was defeated and a Senator's rallying against a bill delayed a crucial vote, in 2007 and 2009 parliament was prorogued, and in 2008 a federal election was called. The most recent public bill, S-204, was introduced in the Senate in March 2010 by one of the Senators responsible for 
several earlier attempts, and received its second reading in June 2010 (Senate Bills to Repeal S.43, 2010, para.6; Senate Public Bill, 2011). There was much hope for this bill to be enacted in the foreseeable future as this was clearly a sustained campaign for law reform. Fast forward to 2011, and again due to federal elections, this fairly well- advanced bill was shelved.

\section{Where Do Other Countries Stand?}

\section{Swedish Benchmark}

38 years ago, in 1979, Sweden was the first country to ban all corporal punishment legislatively, and thus became the first country to forbid all forms of physical violence, including against children, at home (Save the Children, Sweden, 2001).

\section{Other European Countries}

Twenty-nine European states have implemented legislation to completely ban corporal punishment, as of 2016. In chronological order these are Sweden (1979), Finland (1983), Norway (1987), Austria (1989), Cyprus (1994), Denmark (1997), Latvia (1998), Croatia (1999), Germany (2000), Bulgaria ( 2000), Iceland (2003), Romania (2004), Ukraine (2004), Hungary (2005), Greece (2006), Netherlands (2007), Portugal (2007), Spain (2007), Republic of Moldova (2008), Liechtenstein (2008), Luxembourg (2008), Poland (2010), Albania (2010), FYROM (2013), Andorra (2014), Malta (2014), San Marino (2014), Iceland (2015), and Estonia (2016), (Global Initiative, 2016). The Czech Republic, Belgium, Monaco, Switzerland, the UK, and the Russian Federation have all ended corporal punishment in schools, but still allow it in alternative care settings and at home. France is the last European country that still allows corporal punishment both in schools and the privacy of the home. Among the 30 plus countries in Europe, another ten have committed to banning it in the near future. These are Armenia, Azerbaijan, Bosnia \& Herzegovina, Georgia, Lithuania, Montenegro, Serbia, Slovakia, Slovenia, Turkey, and even the above-mentioned France (Council of Europe, 2006).

Great Britain is often used as an instrumental example of a developed country in this debate. There, corporal punishment was legal in classrooms until 1986 when the law brought it in line with most of the other European countries (Robinson, 2009, para, 3). Laws were passed to abolish the spanking and corporal punishment of unruly students in state-run schools in 1986, and in privately funded schools by 1998 (End all Corporal Punishment for Children, 2011, paras. 3-4). Unfortunately, the government has recently confirmed that legislation does not prohibit it in unregistered independent settings providing part-time education. 


\section{Southern Neighbour: The USA}

In the United States, thirty-one states and the District of Columbia have banned the use of corporal punishment in state schools (Gershoff, \& Font, 2016). New Jersey and Iowa have additionally banned the use of corporal punishment in private schools (Bitensky, 2006). However, parents and guardians are permitted to and commonly use corporal punishment to discipline their own children at home, subject to various restrictions (Child Rights Information Network, 2011). Since the U.S. and Canada are culturally related in many ways, social development in one country may surface or influence the other at different times. Knowing what the U.S. is doing puts our own progress here in Canada into perspective.

\section{New Zealand and Australia}

New Zealand is another example in terms of abolishing the corporal punishment of children. It has prohibited all forms of punishment on children in all settings since 2007 (EACPC, 2011, paras. 1-4), and is in compliance with the UN Convention on the Rights of the Child. That being said, in 2009 a National Referendum was held on the question of mild parental corrective techniques (CBC News, 2009, paras. 1-2). The question voted upon was "Should a smack as part of good parental correction be a criminal offence in New Zealand?" Nearly $90 \%$ of respondents voted NO to express their view on this issue (Chief Electoral Officer New Zealand, 2009, p. 2). In geographic and cultural proximity, Australia has prohibited corporal punishment in all educational, caretaking, and alternative care settings since 2012 (GIECPC, 2012).

\section{Asia Region}

In Asia some progress has been made with efforts against corporal punishment, particularly in the school systems of countries including Afghanistan, Bangladesh, India, Nepal, Cambodia, China, Mongolia, Thailand, Fiji and the Philippines, but it is still frequent and prevalent all over the region (GIECPC, 2011, p. 1-2). In 2006 the Republic of China, also known as Taiwan, made corporal punishment in the school system illegal, but it is still known to be practised (Mie, 2011). Singapore, a highly structured country, has no prohibition on corporal punishment both at home and in schools. The same applies for Malaysia and Indonesia (GIECP, 2011, p.1). As in Taiwan, in South Korea corporal punishment is unlawful, but still widely used in schools and homes (UNICEF, 2001, p.15-18). On the other hand, Japan has made considerable progress regarding this issue: it accepted the recommendations from the UN Human Rights Council in 2008, which included the abolition of the corporal punishment of children. Unfortunately, the UN's recommendations have not been enacted as universal law and are not respected everywhere. Authorities struggle to enforce them in the home, alternative care settings, and even 
schools (End All Corporal Punishment, 2011, paras. 1-4).

One cannot help but notice that corporal punishment in schools, if not altogether, is currently prohibited in over half of the world's countries; many of them from the less-developed world. For example, Costa Rica, Venezuela, Uruguay, South Sudan, Togo, Ethiopia, Kenya, Tunisia, South Africa, Trinidad, Tobago and Zimbabwe have banned either all or at least school-related corporal punishment (Save the Children Sweden, 2003, p. 10). Moreover, there have been landmark human rights rulings by Supreme Courts condemning the corporal punishment of children. Countries where corporal punishment has been banned by the highest courts rather than legislation include Israel, Italy, Nepal, Namibia, South Africa, Fiji and Zimbabwe (Save the Children Sweden, 2003, p.10).

All in all, by June 2010, the Stop Hitting Initiative tabulated the abolition of corporal punishment in schools at about 120 countries (Stop Hitting Initiative, 2010, para.6).

\section{Canadian Response to the UN Recommendations}

In 1991 Canada pledged to address the concerns over children's rights raised by the United Nations' Convention on the Rights of the Child (UNCRC), (UNICEF, 2016), which is the world's most ratified human rights treaty. Article 19 of the UNCRC specifically addresses the protection of children from any form of violation, abuse, or preventable injury, both physical or mental in nature (Barnett, 2005).

Corporal punishment has been defined by the United Nations' Convention on the Rights of the Child as follows:

"Any punishment in which physical force is used and intended to cause some degree of pain or discomfort, however light. Most involves hitting ("smacking", "slapping", "spanking") children, with the hand or with an implement - whip, stick, belt, shoe, wooden spoon, etc. But it can also involve, for example, kicking, shaking or throwing children, scratching, pinching, biting, pulling hair or boxing ears, forcing children to stay in uncomfortable position, burning, scalding or forced ingestion (for example, washing children's mouths out with soap or forcing them to swallow hot spices). In the view of the Committee, Corporal Punishment is invariably degrading. In addition, there are other non-physical forms of punishment which are also cruel and degrading and thus incompatible with the Convention. These include, for example, punishment which belittle, humiliates, denigrates, scapegoats, threatens, scares or ridicules the child" (UNICEF, 2016).

Article 19 of the UN Convention on the Rights of the Child (2006) clearly prohibits physical or mental violence against children by their guardians: 
"State Parties shall take all appropriate legislative, administrative, social and educational measures to protect the child from all forms of physical or mental violence, injury or abuse, neglect or negligent treatment, maltreatment or exploitation, including sexual abuse, while in the care of parent(s), legal guardian(s) or any other person who has the care of the child" (UNICEF, 2016).

Did Canada really commit to implementing what it had ratified? After years of evaluation and case study, in 2003 the UN Human Rights Committee made forty-five recommendations for Canada in respect to the human rights of children (Bramham, 2011). The UN expressed their concern by stating in the concluding observations: "The Committee urges the State party to make every effort to address those recommendations contained in the concluding observations on the initial report that have not yet been implemented..." (EACPC, 2010). Apparently 26 years after the Convention on the Rights of the Child was ratified by Canada, Canadians have not moved far from where we stood two and a half decades ago.

In 2006, soon after the Human Rights Council of the United Nations was established, it called for a coordinated and concerted campaign for a total abolition of the corporal punishment of children. The Human Rights Council was established particularly to review the human rights records of 143 countries as part of its first nine Universal Periodic Review sessions from 2008 to 2010 (UN Human Rights Council, 2011, paras. 1-4). Canada was included in the 2009 Universal Periodic Review.

The prescribed abolition of corporal punishment towards children was found to be neglected in over 80 countries, including Canada, which should have been obligated to do so under their ratification of the UNCRC (UNHRC, 2011, para. 3). At least 35 of these states acknowledged and accepted the renewed prohibition recommendation, but unfortunately Canada was not among them (Bramham, 2011). Worse yet, the Canadian government has yet to respond, neither accepting nor rejecting, but rather ignoring the updated request of the UN Human Rights Council altogether (ibid).

In November 2011, the Canadian Coalition for the Rights of Children, which monitors the implementation of the UNCRC, released a progress report (Canadian Coalition for the Rights of Children, 2011) showing a disappointing lack of progress in Canada. Canada had failed to meet several prior recommendations, which included investigating evidence of discrimination against disadvantaged children (Bramham, 2011). The UN expressed regret that many of the recommendations had not been met, or had been insufficiently or only partly addressed. To date, having had fourteen years to work on this, Canada has still not been brought into compliance with the 45 recommendations that the UN committee on children's rights suggested in 2003. 


\section{How do Other Countries respond to the Recommendations?}

As mentioned previously, during the UN Human Rights Council's Universal Periodic Review sessions between 2008 and 2010, thirty-five out of the eighty lacking states accepted the renewed recommendations regarding the treatment of children. Among those thirty-five nations, Japan, Switzerland, Mexico, Saudi Arabia, Slovenia, Slovakia, Turkey, San Marino, the Dominican Republic, El Salvador, and many African countries all accepted the recommendations to fulfill their human right obligations in terms of abolishing the corporal punishment of children (UNHRC, 2011, Table: 141).

Many of the forty-five remaining nations which did not enact the UN's recommendations are understandably among the lesser-developed, such as Somalia which has not shown any effort to realize this treaty. However, even the United States and the United Kingdom have ignored the UN's recommendations (ibid).

\section{Why is the World Increasingly Abolishing the Corporal Punishment of Children?}

This issue ignites heated debates in all corners of the globe, despite much medical and scientific evidence from past decades suggesting the negative impact on children that are physically punished.

The most frequently asked questions are why it is necessary to ban the corporal punishment of children and whether or not the state should have the right to interfere in the privacy of one's own home (Rosemond, 1994). On one side of the debate are parents and educators who believe that the development of good behaviour, social order, and moral conduct requires a reasonable use of discipline, both non-physical and physical. On the other side are those who see physical discipline leading to behavioural problems, and on the extreme side, to the serious abuse of children (Straus \& Donnelly, 1994).

Recent research by New Orleans professors demonstrates an increase in aggressive behaviour by age five in children who are spanked more frequently at age three. "Corporal Punishment contributes to a climate of violence; it implies that society approves of the physical violation of children" (Lee, Manganello, Rice, \& Taylor, 2010, p.795-796).

Psychologist H. Stephen Glenn, who has served in various US state, federal and international organizations, said "Corporal Punishment is the least effective method [of discipline]. Punishment reinforces a failure identity. It reinforces rebellion, resistance, revenge and resentment" (U.S. Advisory Board on Child Abuse and Neglect, 1991, p.124).

\section{Impacts on Learning Outcomes and Cognitive Development}

Studies have been undertaken by many professionals in various fields. The executive director of the Canadian Institute of Child Health stated: "We 
know that children who are under the threat of violence or aggression develop a fight-or-flight response system that has an impact on creativity and imagination, both of which could influence their IQ" (Turner, 2002, p. 214216). A study conducted at the University of New Hampshire concluded that spanking children slows their intellectual development (Gadd, 1998).

A recent project by Professor Talwar of McGill University, Professor Carlson of the University of Minnesota, and Professor Lee of the University of Toronto studied two West African private schools involving 63 children in kindergarten or first grade. The results of this study showed that pupils who had experienced corporal punishment in the first school displayed divergent psychological development, such as reduced executive functioning for tasks requiring planning, abstract thinking, and delaying gratification, compared with peers being disciplined by milder measures such as time-outs, in the second school (Carlson, Lee, \& Talwar, 2011, para. 2). What these results seem to prove is that there are long-term negative effects of a harshly punitive environment on children's intelligence and healthy executive functioning. The study also suggests that children affected by corporal discipline, due to the resulting deficits in executive functioning, are more at risk for subsequent behavioural problems.

These findings support other research results suggesting that corporal punishment may make children immediately compliant, but may hinder their long-term internalization of rules and conventions. This could in turn result in lower self-control as these children grow up (Centre for Justice and Crime Prevention, 2011, para. 5). "With this new evidence that [corporal punishment] might actually undermine children's cognitive skills needed for self-control and learning, parents and policy makers can be better informed," concluded Carlson, Lee and Talwar (2011, para. 9) of the University of Minnesota.

\section{Encouraging Anti-Social Behaviour in Children}

Children who experience corporal punishment will learn to recognize when adults are displeased, but not why. Harsh punishment causes a state of confusion and severe distress which makes it unlikely that a child will be able to analyse their behaviour clearly. Physical punishment will also often provoke, especially in older children, resentment and further misbehaviour. Andrew Grogan-Kaylor of the University of Michigan stated that "Even minimal amounts of spanking can lead to an increased likelihood in antisocial behaviour by children (2004, para. 3)". From the Family Research Lab of the University of New Hampshire, Murray Straus and Denise Donnelly (1994), considered influential scholars on violence, addressed in their publication Beating the Devil out of Them that corporal punishment correlates with childhood depression, self-harm, and suicide, that often persist throughout adulthood. Straus and his coauthor argue that physical punishment such as spanking, even when administered by loving parents who have no desire to be cruel, encourages children to believe that problems can be solved by violence (Straus, \& Donnelly, 1994). 


\section{Fostering Criminality and Delinquency}

Dr. Ralph Welsh, a Clinical Psychologist, made the following observation:

"...it is now apparent that the recidivist male delinquent who was never struck with a belt, board, extension cord, fist, or an equivalent is virtually nonexistent. Even after 10 years, the full impact of this discovery is still difficult to comprehend" (Welsh, 1978, p. 342). Welsh has examined and evaluated over 3,000 young offenders over his decade-long career and has observed a very strong connection between severe childhood corporal punishment and rage, criminality, and further violence in adulthood. Welsh concluded that "all of the data suggests that Corporal Punishment as a disciplinary technique is very dangerous, is the major contributor to our crime rate, and tends to perpetuate itself" (2007, para. 12).

Other studies conducted at Harvard University and Maclean Hospital also show a connection between experiences during children's formative years and their tendency to commit violent acts later in life. Abused children are more likely to develop brain neurochemistry programmed for violence (Eisler, 2005). If we don't intend to cultivate young offenders in our society, eliminating the corporal punishment of children seems the most rational and cost effective course of action.

\section{Risk of Abusive Behaviour}

Could well-meaning parents or educators somehow go over board? This is a concern, even to many opponents of a physical discipline ban. Violence against children has a long history and may be a deliberate act of discipline, but is often the impulsive reaction of an irritated guardian. As summarized above, the idea that corporal punishment, even in its mildest forms, encourages children to become healthy, productive citizens, has been clearly refuted by recent scientific research which indicates that the exact opposite is true (Pollard-Sacks, 2003). The Council of Europe stated that the "Corporal Punishment of children often becomes inhuman or degrading, and it always violates their physical integrity, demonstrates disrespect for human dignity and undermines self-esteem" (Council of Europe, 2008, para. 5). In every circumstance, it is a violation of children's fundamental human rights, frequently inflicted by those whom they should be able to trust the most.

Does allowing or ignoring corporal punishment legitimize potentially abusive behaviour? In many countries, including Canada, protecting parents' or teachers' rights becomes a focus point of the issue, causing major setbacks. It seems to frequently be the sticking point for any real progress. We all know that actual physical damage inflicted upon a child via corporal punishment can be horrifying. Serious physical injuries can occur where discipline becomes child abuse (Goddard, 2003). Understandably, adults may believe that some mild forms of corporal punishment are in the child's best interest, however 
child-abusers can use this in defence of their true intentions. It becomes impossible to differentiate the two when it comes down to motive, and problematic to police regardless of intent.

There is a large body of evidence from international research to suggest the aforementioned escalation of minor corporal punishment. Those convicted of violent assaults often started very small. Over the years, the severity of corporal abuse tends to escalate as victims become conditioned to this illtreatment, or grow older. Thus, tragic events occur and worsen.

It has been shown that there are always effective ways to discipline children without violence; it just takes patience, energy and good intention. Therefore, employing corporal punishment as a "last resort" is simply an easier, faster, and lazier way to discipline children (Couture, 2003, paras. 3-4), and as previously mentioned, proven ineffective in the long run.

\section{Does Canada Meet the World Standard?}

If one compares Canada with less-developed nations, it might be considered above average. However, should Canada feel satisfied comparing itself with nations without adequate sanitation or housing, or those still fighting illiteracy and high infant mortality rates? Looking at the developed countries, does Canada do a justifiable job? One may argue that the US and UK do no better, and that Switzerland's progress is fairly similar. That being said, Australia, Germany, the Netherlands, Spain, and the Scandinavian countries are well ahead of Canada. Even Croatia, Bulgaria, Romania, the Ukraine and Poland, which only opened up to the rest of the world after the fall of Communism in 1989, are doing better.

So, why do Canadians discipline their children differently from most others in the world? "The concepts of 'reasonable chastisement' and 'lawful correction' in the law" that arose "from the perception of children as the property of their parents" (Durrant, 2007, p.106) should be long gone. Such outdated practices have been abandoned by the majority of developed nations, yet Canada treats their own children with comparatively less protection. Are adult Canadians primarily concerned with the threat of prosecution, and willing to pay with their children's emotional and intellectual growth? Thus far, the government and public have placed parents' and teachers' concerns ahead of children's fundamental security and equality rights.

\section{Recommendations and Conclusion}

In countries that have not yet fully prohibited corporal punishment, such as Canada, the public must be made to understand that such a ban would not be punitive nor an intrusion into classrooms, but educationally and emotionally beneficial for society as a whole.

Per the United Nations Committee on the Rights of the Child, "The first 
purpose of law reform to prohibit Corporal Punishment of children within the family is prevention: to prevent violence against children by changing attitudes and practice, underlining children's right to equal protection and providing an unambiguous foundation for child protection and for the promotion of positive, non-violent and participatory forms of child-rearing..." (UNCRC, 1989).

Few will argue that prevention is the most effective and efficient solution for many social problems. What makes prevention challenging is the time required and costs that are often not reflected by immediate results. That been said, preventing childhood corporal punishment remains the best method of reducing violence and defiance at the source.

Recent research has shed more light on how parents or care providers should behave and react to children to prevent the development of future delinquency and to foster their full potential. Care givers should display "parental behaviour based on the best interests of the child that is nurturing, empowering, non-violent and provides recognition and guidance which involves setting of boundaries to enable the full development of the child" (Council of Europe, 2006, para. 1).

It is time to review all relevant legislations to ensure successful prevention of all corporal punishment at every level, including, but not limited to, examining the Canadian Criminal Code, the Youth Criminal Justice Act, and all school board policies, particularly in Ontario, Alberta, and Manitoba (McGillivray \& Durrant, 2006). The long-due law reform to abolish the corporal punishment of children, a successful repeal of Section 43, would place Canada alongside the group of nations that have already abolished physical discipline and upheld the universal rights of children. Under newly elected leadership, Calls for Action (Commission of Canada website) has been called upon to redress the legacy of residential schools and accelerate the process of reconciliation. In the Calls for Action plan, a recommendation directly related to corporal punishment is listed as the top priority under the Education category: "We call upon the Government of Canada to repeal Section 43 of the Criminal Code of Canada." This repeal would bring Canada one step closer to the standard many developed nations have already embraced for decades.

In addition, assuming that changes to the national law are sufficient to end such practices is out of touch with reality. Japan, which banned the practice legislatively, is a perfect example since corporal punishment is still prevalent in the daily lives of children (EACPC, 2010). For corporal punishment to become a thing of the past, a nation requires more than legislation banning it. Awareness has to be raised through public education, by and with parents and anyone working with children (McGillivray \& Milne, 2011). Society must be persuaded and educated on the rationales for abandoning corporal punishment, children's rights to protection, and the existing laws and treaties. This awareness, as well as the promotion of positive, non-violent, mutual relationships with children, is essential for the success of any new legislation. Such information should be integrated into school curriculums and disseminated through the mass media.

The implementation of a ban on corporal punishment would require 
guidance and support for everyone working with children and their families. This should include clear guidance for professionals on their role in preventing any violations of the ban and how to properly respond in varying situations. Teachers, daycare employees, care providers, health personnel, and social workers need to learn to recognize when a child suffers violence and needs help. Again, a sustainable and long-term public education campaign will be necessary to challenge the deeply-entrenched traditions of humiliating physical punishment.

Finally, continuous research is critical to develop a better handle on the magnitude and nature of damage inflicted by the practice of corporal punishment. Such research should also continuously identify groups of children at high risk, and aim to significantly reduce the harm inflicted upon our most vulnerable citizens.

In short, peaceful conflict resolution, communication, tolerance and mutual respect can only be taught to, and learnt well, by children when these values are exemplified by the adults who raise and educate them. Are we "there" yet? Sorry children, not quite.

\section{References}

Barnett, L. (2005). Effective implementation of Canada's international obligations with respect to the rights of children. (Interim Report 19th.). Standing Senate Committee on Human Rights. Retrieved from http://bit.ly/2neP0Mg.

Barnett, L. (2008). The "Spanking" Law: Section 43 of the Criminal Code. (Research Publication No. PRB 05-10E). Retrieved from http://bit.ly/2milapA.

Bitensky, S. H. (2006). Corporal Punishment of Children: a human rights violation. Ardsley, NY: Transnational Publisher.

Bramham, D. (2011, Nov. 1). Good intentions go unfulfilled. The Vancouver Sun, p. A10.

Brown, F. A., \& Zuker, A. M. (2007). Education Law (4th ed.). Toronto: Thomson Canada Limited.

Canadian Charter of Rights and Freedoms. (1982). Retrieved from http://bit.ly/2mh $\mathrm{BYjR}$.

Canadian Coalition for the Rights of Children. (2011). Right in Principle, Right in Practice. Retrieved from http://bit.ly/1HcACzY.

Carlson, S., Lee K. L., \& Talwar, V. (2011). Spare the rod and develop the child. Retrieved from http://bit.ly/2mUPVYh.

Canadian Children's Rights Council. (n.d.). About the UN Convention on the Rights of Children (UNCRC). Retrieved from http://bit.ly/2lVCg3S.

CBC News, Canada. (2009, July 31). To spank or not to spank? Retrieved from http://bit.ly/2mEgWNx.

Centre for Justice and Crime Prevention. (2011). National Schools Violence Study. Retrieved from http://bit.ly/2mLJhAQ.

Council of Europe. (2006). Committee of Ministers Recommendation 19, on policy to support positive parenting. Retrieved from http://bit.ly/2nV9Svr.

Council of Europe. (2008). The right not to be hit, also a child's right. Retrieved from http://bit.ly/2nyJJCy.

Couture, L. (2003). 10 Pro-Corporal Punishment Arguments \& 10 Commonsense Answers. Stop Hitting Initiative. Retrieved from http://bit.ly/2n3UiRm. 
Criminal Code of Canada, R.S.C. 1985, c. C-46. (1985). Retrieved from http://bit.ly/ 1 jf6ODO.

Chief Electoral Officer. (2009). Citizens Initiated Referendum 2009 - Final Result. Ministry of Justice. New Zealand. Retrieved from http://bit.ly/2mZtqC9.

Child Rights Information Network (CRIN). (2011). National Law. Information by Country: United States. Retrieved from http://bit.ly/2mhXLY2.

Durrant, E. J. (2007). Corporal Punishment: A Violation of the Rights of the children. In B. R. Howe, \& K. Covell, A Question of Commitment: Children's right in Canada (pp. 99 - 125). Waterloo: Wilfrid Laurier University Press.

Durrant, J., Trocmé, N., Fallon, B., Milne, C., Black, T., \& Petrowski, N. (2009). Physical punishment of children: Assessing the validity of the legal definition of "reasonable force." CECW Information Sheet \#71E. Toronto, ON, Canada: University of Toronto Factor-Inwentash.

Eisler, R. (2005, Winter). Spare the Rod. Yes! Magazine. Bainbridge Island, WA.

End All Corporal Punishment of Children (EACPC) (2010). UNCRC Committee Comment Organized by State: Canada. Retrieved from http://bit.ly/2mZfIyO.

End All Corporal Punishment of Children (EACPC) (2010). Japan Report. Retrieved from http://bit.ly/2neCzXJ.

End All Corporal Punishment of Children EACPC) (2011). New Zealand, United Kingdom and United States Reports. Retrieved from http://bit.ly/2neCzXJ.

Gadd, J. (1998, July 30). Spanked Children Suffer Intellectually. The Globe and Mail. Toronto ON.

Gershoff, E.T., \& Font, S. A. (2016). Corporal Punishment in U.S. Public Schools: Prevalence, Disparities in Use, and Status in State and Federal Policy. Social Policy Report, 30(1), 1-26.

Goddard, J. (2003). When Spanking Kids Cross the Line. The Toronto Star. Retrieved from http://bit.ly/2mmfAVR.

Global Initiative to End All Corporal Punishment of Children \& Save the Child, Sweden (GIECPC) (2012). Ending legalized violence against children. (Global Report). Retrieved from http://bit.ly/2nyMweM.

Global Initiative to End All Corporal Punishment of Children \& Save the Child, Sweden (GIECPC) (2011). Ending legalized violence against children. (Global Report). Retrieved from http://bit.ly/2nyALF2.

Global Initiative to End All Corporal Punishment of Children (GIECPC) (2015). Canada Progress Report. Retrieved from http://bit.ly/1OzDZlV.

Global Initiative to End All Corporal Punishment of Children (GIECPC) (2011). East Asia and Pacific Progress Reports. Retrieved from http://bit.ly/2mRIWAF.

Grogan-Kaylor, A. (2004). Spanking can lead to more bad behaviour. Retrieved from http://bit.ly/2nJfsBM.

Lee, S.J., Manganello, J.A., Rice, J.C., \& Taylor, C. (2010). Adolescent Violence Perpetration Associated with Multiple Types of Adverse Childhood Experience. Paediatrics, 125(4), 795-796.

McGillivray, A. E., \& Durrant, J.E. (2006). Child Corporal Punishment: Violence, Law, and Rights. In Alaggia, R. \& Vine, C. (Eds.), Cruel but Not Unusual: Violence in Canadian Families (pp.177-200). Waterloo: Wilfrid Laurier University Press.

McGillivray, A. E., \& Milne, C. (2011). Canada: The Rocky Road of Repeal. In J. E. Durrant \& A. B. Smith. (Eds.), Global pathways to abolishing physical punishment: realizing children's rights (pp.98-111). New York: Routledge.

Mie, T. (2011, July 22). Re: Corporal Punishment and Racial Identity. [Web log comment]. Retrieved from http://bit.ly/2mZftUq.

Orucu, E., \& Nelken, D. (2007) (eds.) Comparative Law: A Handbook. Oxford: Hart. 
Pollard-Sacks, D. (2003). Banning Child Corporal Punishment. Tulane Law Review, 77(3), 575-658.

Reimann, M. \& Zimmermann, R. (2008) (eds.) The Oxford Handbook of Comparative Law. Oxford: Oxford University Press.

Repeal 43 Committee. (2011). Senate and House of Commons Bills to Repeal S. 43. Retrieved from http://bit.ly/2mRmaaI.

Riak, J. (2003). Plain Talk about Spanking. Parents and Teachers against Violence in Education. Health \& Recovery Issues for Children, Adults, and Society. Retrieved from http://bit.ly/2nitspe.

Robinson, B.A. (2009). Child corporal punishment: spanking. Ontario Consultants on Religious Tolerance. Retrieved from http://bit.ly/21Skizv.

Rosemond, J. K. (1994). To Spank or Not to Spank. A Parent's Handbook. London: Andrews McMeel Publishing.

Save the Children, Sweden. (2001). The first anti-spanking law in the world: Historical background to the Swedish legislation. Council of Europe. Retrieved from http://bit.ly/2mB1DoG.

Save the Children, Sweden. (2003). Hitting People is Wrong-and Children are People Too. Retrieved from http://uni.cf/2nkwmGB.

Senate Bills to Repeal S.43. (2010). Bill s-207. An Act to Amend the Criminal Code (Protection of Children). Retrieved from http://bit.ly/2mH7GcZ.

Senate Public Bill. (2011). Bill s-204. An Act to Amend the Criminal Code (Protection of Children). Retrieved from http://bit.ly/2mmx0BD.

Stop Hitting Initiative. (2010). Discipline and Law, Legal Reforms. Retrieved from http://bit.ly/2nkFmLP.

Straus, M. A., \& Donnelly, D. A. (1994). Beating the Devil Out of Them: Corporal Punishment in American Family. New York: Lexington Books.

Truth and Reconciliation Commission of Canada, Final Report (2015). Retrieved from http://bit.ly/1m7KHxx.

Turner, S. (2002). Something to cry about: an argument against corporal punishment of children in Canada. Waterloo: Wilfrid Laurier University Press.

UNICEF, Region Office for South Asia. (2001). Corporal Punishment in Schools in South Asia. (Discussion on violence again Children). Retrieved from http://bit.ly/ 21Sfaeu.

UNICEF. (2016). Convention on the Rights of Child - Canada. Retrieved from http://bit.ly/ 1MVzqBy.

United Nations Convention on the Rights of the Child (UNCRC) (1989). Adopted and opened for signature, ratification and accession by General Assembly resolution 44/25 (Doc. A/RES/44/25). Retrieved from http://bit.ly/2neNfWk.

United Nations Convention on the Rights of the Child. (UNCRC) (2006). The Right of the Child to Protection from Corporal Punishment and Other Cruel or Degrading Forms of Punishment. (United Nation General Comment No. 8). Retrieved from http://bit.ly/21SswYh.

United Nations, Human Right Council (UNHRC) (2011). Corporal punishment of children. (Universal Periodic Review). Retrieved from http://bit.ly/2neCzXJ

U.S. Advisory Board on Child Abuse and Neglect. (1991). A Nation's Shame: Fatal Child Abuse and Neglect in the United States. Retrieved from http://bit.ly/21SgQ7D.

Watkinson, A. M. (2007). Corporal punishment and education: Oh Canada! Spare us!. In M. Manley-Casimir, \& K. Manley-Casimir, (Eds.), The courts, the charter and the schools: The impact of the Charter of Rights and Freedoms on educational policy and practice, 1982-2007 (pp. 181-199). Toronto, ON: University of Toronto Press. 
Watkinson, A. M. (2006). Supreme Court of Canada stands behind corporal punishment sort of. International Social Work Journal, 49(4), 531-536.

Welsh, R. S. (1978). Delinquency, Corporal Punishment, and the Schools. Crime and Delinquency 24, 336-354.

Welsh, R. S. (2007). The Dangers Associated with Hitting Children. Project No Spank. Retrieved from http://bit.ly/2nkJPhF. 
